\title{
The Importance of Sustainable Development of Travel and Tourism Industry in the Turnover of Foreign Visitors: The Case of Kosovo
}

\author{
Submitted 11/03/21, $1^{\text {st }}$ revision 12/04/21, $2^{\text {nd }}$ revision 08/05/21, accepted 25/05/21 \\ Blerina Bytyqi ${ }^{1}$, Pajtim Rrustemi $^{2}$, Alberta Tahiri $^{3}$, Idriz Kovaçi ${ }^{4}$
}

\begin{abstract}
:
Purpose: The main purpose of this paper is to give an overview regarding the importance of travel and tourism industry, its development and sustainability. Given that the development of this industry contributes to the overall development of the economies of different countries, it is intended to present the importance of sustainable development of the travel and tourism industry in the turnover of foreign visitors in Kosovo.

Design/Methodology/Approach: The research is based on secondary data obtained from quarterly reports of hotel statistics published by the Kosovo Agency of Statistics. These data refer to the number of foreign visitors by purpose of trip for which they have taken the initiative to come to Kosovo. Overall, a comparison has been made in the years 2017-2019 and the trend of the number of foreign visitors has been presented.

Findings: Trips undertaken for the purpose of visiting friends and relatives are the highest in number. The number of foreign visitors has marked an increasing trend during the years 2017-2019. Reports have shown that foreign visitors entering Kosovo came from different countries, respectively registered during the crossing of border points. The highest figures were recorded by visitors from Serbia, Albania, North Macedonia, Germany, Switzerland, and Montenegro.
\end{abstract}

Practical Implications: This paper clearly and concisely presents the importance of sustainable development of the travel and tourism industry, with emphasis on its impact on the economic development of countries.

Originality/Value: The paper presents the personal research of the authors with their clear intention to provide a theoretical overview, illustrated with the analysis of secondary data, of the topic on which the discussion extends.

Keywords: Travel and tourism industry, development, sustainability, visitor turnover.

JEL code: Z32.

Paper type: Research article.

\footnotetext{
${ }^{1}$ University of Applied Sciences in Ferizaj, Faculty of Tourism and Environment, Ferizaj Kosovo, E-mail: blerina.bytyqi@ushaf.net

${ }^{2}$ Corresponding author, as in 1, E-mail: pajtim.rrustemi@ushaf.net

${ }^{3}$ University of Applied Sciences in Ferizaj, Faculty of Tourism and Environment, Department of Tourism and Hotel Management, Ferizaj, Kosovo, E-mail: alberta.tahiri@ushaf.net

${ }^{4}$ As in 3, E-mail: idriz.kovaci@ushaf.net
} 


\section{Introduction}

Tourism is increasingly the centre of popular and policy discourses. It is both demonized and idealized, as a destroyer and a creator, whether of valued environments, social and cultural practices, or wealth. One of the roles of tourism researchers should be to provide a greater understanding of the underlying processes that shape the emerging tourism landscape. Although there are a growing number of exceptions, tourism research is still often descriptive, atheoretical, and chaotically conceptualized in being abstracted from broader social relationships (Shaw and Williams, 2004).

Tourism is an international/global industry that captures the complex interaction of a variety of environmental factors. Tourism development draws upon a multitude of disciplines and subject areas such as anthropology, business, communication, cultural, economics, geography, history, hospitality, politics, psychology, retailing, sociology, and transportation etc. The international and interdisciplinary nature of the field of tourism is well recognized by academics, professionals and policy makers (Manhas et al., 2016; Adamopoulos and Thalassinos, 2020).

The rapid increase in travel we are now experiencing leads to many manifestations on both environmental and social systems. Development of tourism opportunities to take advantage of the increase in travel has been the centre of much debate in academia, by activists and by managers of the protected areas that often serve as the product base. This discourse has been informed by a variety of disciplines and has concluded that integrated frameworks are needed to successfully deal with the consequences of touristic activity. The authors in this part discuss the need for systematic frameworks and approaches to integrate cultural and environmental issues in tourism development decision making. In so doing, they suggest some useful approaches and illustrate through several case studies the intricate relationships between these two domains. The fundamental proposition of this part is that successful tourism development occurs only through the use of frameworks that explicitly impact these two dimensions and their interactions. The environmental impacts of tourism are fairly well understood and documented, but the rise of ecotourism and nature-based touristic activity has often shifted the locus of impacts to more undeveloped and fragile locations. With this shift, impacts are more related to tourist behaviour than either numbers or large-scale infrastructure (McCool and Moisey, 2008).

Travel and tourism play a critical role in the economies of tiny villages and huge countries (Sharma, 2006). However tourism is defined, most people would include the elements of movement (transportation), of remaining temporarily in one place (accommodations), consuming food and drink (which could be an attraction), and participating in activities (attractions). The transportation sector generally includes airlines and airports, trains, buses, taxis, private automobiles, boats and ferries, the servicing and repair of these transportation modes, and travel agents and tour 
companies that facilitate transportation. The accommodations sector can include hotels, motels, resorts, campgrounds, the homes of friends and relatives, cruise ships, accommodation booking agencies and businesses that service these different accommodations (Lew et al., 2008). The challenge of the sustainable development concept is how to balance environmental conservation (the sustainable part) with economic development (the development part) (Lew et al., 2008).

\section{Literature Review}

The new challenges facing the tourism industry, as well as its specific characteristics and structure, are creating a need for more in-depth knowledge about the factors that affect and shape this industry (Andrew et al., 2007; Singal, 2015; Segui-Amortegui et al., 2019). An industry is defined as a set of businesses that share in the production of a common product. For example, the auto industry consists of businesses that manufacture, sell and service automobiles. A set of businesses must meet three criteria to be considered an industry (Lew et al., 2008):

1. They produce essentially the same product;

2. They use essentially the same technology;

3. The product output is large enough to warrant data collection and reporting.

The beginning of the new millennium is characterized by the affirmation of globalization as a world trend, which has its strong influence in all spheres of the socio-economic system, including tourism. It can be said that there is no business entity, which remains spared from the effects of permanent changes that occur in all areas of the environment, whether nationally or internationally (Tahiri and Kovaçi, 2017).

\section{The Importance of Travel and Tourism Industry}

The term tourism has evolved throughout the 20th century and today inhabits the imaginary and everyday life of much of the world's population. The term tourism is used to characterize a sociocultural phenomenon that involves transport, motivations, accommodation, hospitality, impacts and the economic, cultural, social and environmental sectors affected and fuelled by the movement of people around the world. Tourism means much more than can be expressed by a simple word, and it may be seen as both reflecting social practices and involving social representations. The most common views of tourism include holidays, travel, rest, leisure and pleasure, and an escape from reality; it also generates employment and income and spreads culture. Tourism is the sum of the phenomena resulting from travel or movement away from one's habitual place of residence and economic activity.

However, these views do not express the complexity of the phenomenon. Tourism permeates much of human actions and the world economy. We understand it as the 
"phenomenon of human beings leaving and returning to their usual place of residence, for clear or hidden reasons, which implies hospitality, meeting and communication with other people and using technology, among numerous other conditions, which will generate varied experiences and different impacts" (Lohmann and Netto, 2017). Tourism is one of the largest service industries in the world.

The demand for travel and tourism continues to increase, despite terrorist threats, and especially as leisure time and economic well being increase in the newly developing economies of Asia, Latin America, Eastern Europe and elsewhere (Lew et al., 2008). Most people dream of working at something that they find to be interesting, challenging, and fun-something that they enjoy doing even after work hours arc over. Travel is such an activity. For many travel is a dream of a lifetime and working at a job that makes it possible to travel can be a dream come true. A career in travel is considered very glamorous and adventurous. Once inside the industry, however, some people find that the reality of hard work, long hours, and low pay dulls the glow. Most people who have not simply fallen into a career in travel seek it because they love to travel (Sharma, 2006).

\section{The Tourism System}

Neil Leiper, author of the most well-known tourism system on an international level, proposed a model composed of five elements, including three geographical elements (Lohmann and Netto, 2017):

- The traveller-generating region (the origin or environment where the travellers usually live);

- A transit region that connects the origin to the destinations;

- The tourism destination region.

The other two elements are (Lohmann and Netto, 2017):

- The tourist;

- The tourism and travel industry (tourist information centres, lodging establishments, etc.).

According to Leiper (1990), the interaction of these five elements is influenced by external environmental factors and, in turn, the system impacts various environments (e.g. the human, socio-cultural, economic, technological, physical, political and legal environments), influencing how travellers pass through the transit region (Figure 1). The schema provided in Figure 1 also shows where the various suppliers that comprise the tourism system are located. The tourism-generating region, for example, contains the travel agencies that send the tourists, along with the marketing and promotion companies that want to influence touristic demand. The transport and distribution and communication channels operate between the generating regions and the destination regions. 
Figure 1. Leiper's tourism system model (From Leiper, 1990)

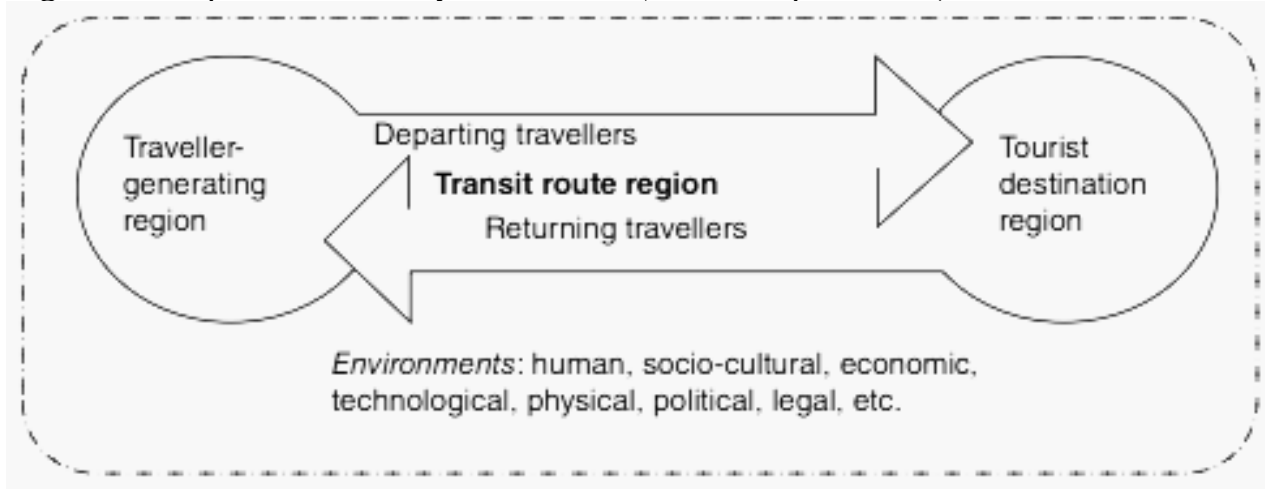

Location of travellers/tourists and the travel and tourism industry

Source: Lohmann, G. and Netto, A.P. (2017). Tourism Theory: Concepts, Models and Systems, CABI, United Kingdom.

Finally, the destination region contains the lodging sector and tourist attractions. Through the schema, it is clear that the tourist experience begins in the generating region, passes through the transit region and arrives at the destination region. In Leiper's system, each element both interacts with and is impacted by the system that contributes to the existence of the touristic product (Lohmann and Netto, 2017).

\section{Sustainable Tourism}

Since it first emerged some 20 years ago, the concept of sustainable tourism development has achieved and maintained, at least in policy circles, "virtual global endorsement as the new (tourism) industry paradigm" (Godfrey, 1996). A growing proportion of the academic and policy orientated tourism literature is now devoted to examining the theory and practice of "sustainable tourism" (ST). It is now widely accepted that any quest for a universally applicable definition of sustainable development (SD) is not likely to be successful, and in recent years sustainability theory has advanced through the articulation of a range of possible interpretations of SD and their applicability under a variety of circumstances (Hunter, 2002).

With its alluring premise of continued development that does not unduly harm a destination's natural and sociocultural environment, the idea of sustainable tourism has emerged as a priority objective of the global tourism sector since the mid1990s. This is indicated in part by the extent to which it has been officially recognized and internalized by a broad array of international, regional and national organizations both internal and external to tourism. Yet, as attempts have subsequently been made to operationalize the concept in the actual planning and management of tourism businesses and destinations, various attendant issues and challenges have become increasingly apparent (Weaver, 2006). 
Just as sustainable development more generally is dependent upon sustainable consumption, the consumption of tourism in particular is of direct relevance to its (sustainable) developmental contribution - the scale, scope and nature of the demand for tourism represent significant challenges to sustainable development (Sharpley, 2009; Adamopoulos and Thalassinos, 2020).

Sustainable tourism is an area of interest of many scholars, activists and practicians in various countries. It seems, though, that both in the international and in the Polish literature the descriptive method dominates. It puts stress on explaining the conception of sustainable tourism, which is often done from different scientific positions. Apparent is the evolution of views on its essence. In the first period natural aspects were emphasized first of all - in the context of preserving natural environment resources against the threats of tourism. Now, however, we are dealing with the situation in which economic and socio-cultural aspects are seen as well. To a large extent it is thanks to i.a., the publications of the United Nations World Tourism Organization, which emphasized the necessity of striving for balance in fulfiling needs of all tourism stakeholders functioning within natural and socio-economic environment. The change in the approach towards sustainable tourism during past few decades is also expressed in the abandonment of evaluation of various tourism forms according to these criteria. Nowadays, it is stressed that the principles of sustainable tourism should be taken into consideration in all kinds of tourism, including so unpopular among the "orthodox activists" mass tourism (Kasimoğlu, 2012).

Sustainable tourism may be regarded most basically as the application of the sustainable development idea to the tourism sector - that is, tourism development that meets the needs of the present without compromising the ability of future generations to meet their own needs (Weaver, 2006).

\section{Research Methodology}

This paper is designed based on research in various sources of knowledge, information, and data. Among these sources we mention:

- Books,

- Scientific works,

- State reports,

- Internet sources, etc.

Based on this research, a theoretical approach has been created regarding the topic discussed in this paper. The practical part of the paper contains data provided by quarterly reports of hotel statistics published by the Kosovo Agency of Statistics. So, the data used in this paper are secondary data, and based on them certain analyses have been made from which we have taken the following results. 


\section{Results}

Participation in the tourist turnover of the peoples of different countries and regions day by day is becoming a necessity of the time. Different countries for their population which do not have enough free means intervene in the form of subsidies to help those categories who do not have the opportunity to participate in tourism. In different countries the mentioned interventions have been applied to those categories of workers who have been employed in heavy work especially those professions which have been harmful to the health of workers. These subsidies which were given to these strata with the worst social situation by the state depended on the economic development of each country.

In many countries there are different forms of subsidy which are presented in ways like different clubs, associations of athletes and climbers which are assisted by the state in the form of financial subsidies in building tourism capacity, in various forms of participation as relief in transport and tourist promotion. The thirteenth salary is provided as a form of subsidy to help free means in some countries with more developed economies. This makes it easier to participate in tourist trips to different countries of the world (Reçica and Millaku, 2011).

Table 1. Number of foreign visitors by purpose of trip in 2017 - 2019

\begin{tabular}{|c|c|c|c|c|c|c|c|}
\hline \multirow[b]{2}{*}{ Period } & \multicolumn{7}{|c|}{ Purpose of trip } \\
\hline & $\begin{array}{l}\text { Holidays } \\
\text { \& visit }\end{array}$ & $\begin{array}{l}\text { Visit to } \\
\text { friends } \\
\text { and } \\
\text { relatives }\end{array}$ & $\begin{array}{l}\text { Business } \\
\text { visit }\end{array}$ & Work & Transit & Other & Total \\
\hline 2017 & 43,389 & $3,299,133$ & 97,428 & 13,751 & 167,391 & 859,490 & $4,480,582$ \\
\hline 2018 & 91,904 & $3,546,257$ & 96,148 & 12,824 & 128,783 & 831,869 & $4,707,785$ \\
\hline 2019 & 193,662 & $3,778,181$ & 85,850 & 9,147 & 110,647 & 784,848 & $4,962,335$ \\
\hline
\end{tabular}

Source: Kosovo Agency of Statistics (KAS), Series 3: Economic Statistics, Hotel Statistics Q3 2020 .

Table 1 presents data on the number of foreign tourists according to the criterion of the purpose for which they undertake the trip. The data are presented for a period of three years, respectively for the years 2017-2019. Trips for the purpose of visiting friends and relatives are the highest in number and this figure has increased from one year to another. Then, high figures are shown to trips for other purposes except these categories mentioned above.

Figure 2 represents graphically the data of Table 1 . If we make a comparison of the purpose of trip and the number of foreign visitors, we can say that visit to friends and relatives have the highest figures, higher figures stand for other purposes of trips and the third place goes to transit trips. It is worth noting that trips for holiday and visits have marked a significant increase in 2019, respectively in Kosovo during this year came 193,662 foreign visitors, compared to 2018 when there were 91,904 foreign visitors and in 2017 there were 43,389 foreign visitors. 
Figure 2. Graphical representation of the number of foreign visitors by purpose of trip in $2017-2019$

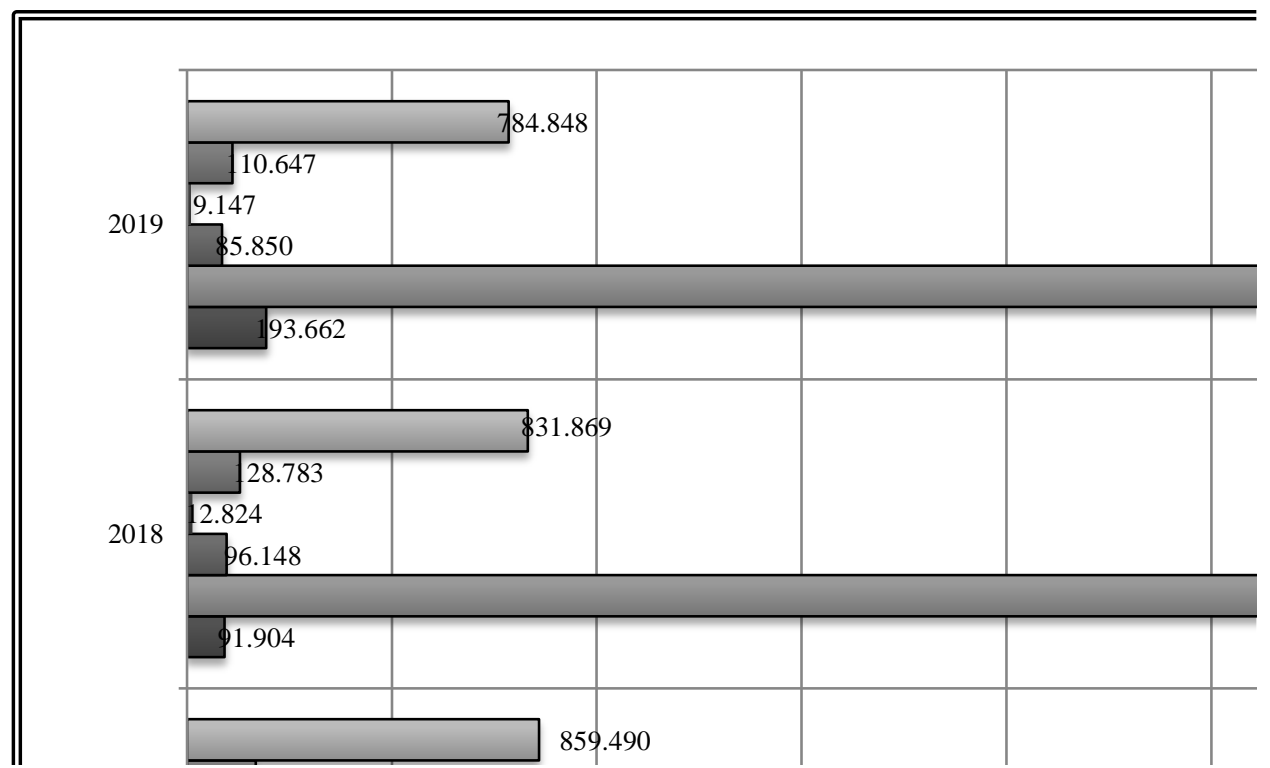

Source: Compiled by authors based on the data of Table 1.

Figure 3. The trend of the total number of foreign visitors by purpose of trip in 2017 $-2019$

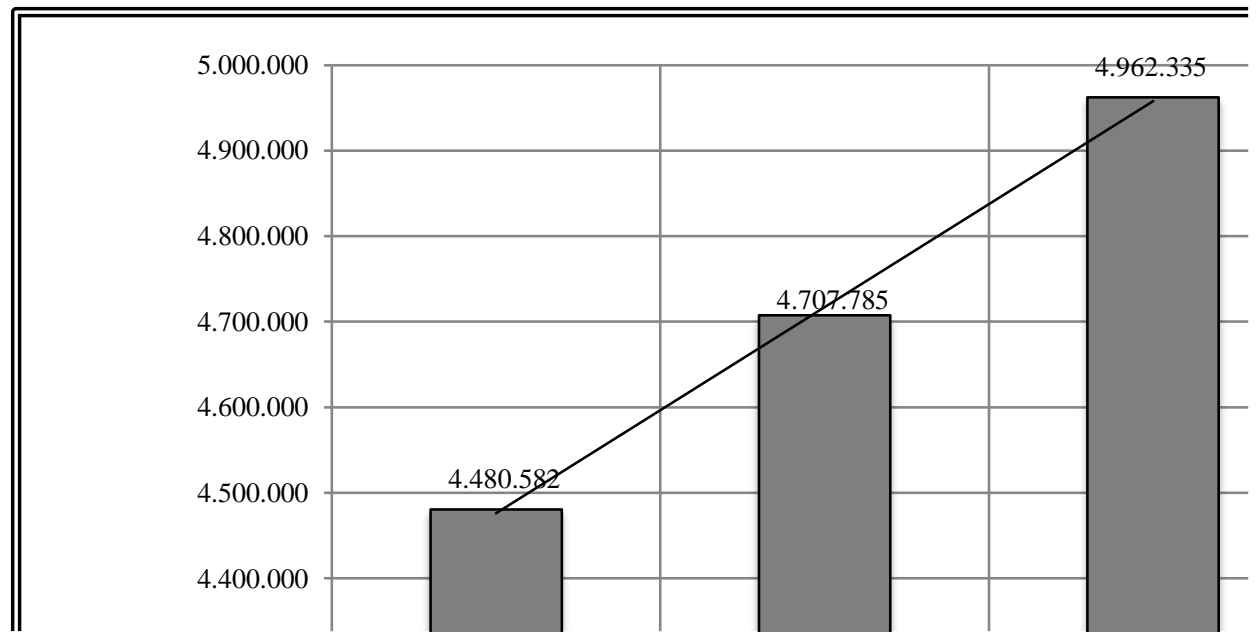

Source: Compiled by authors based on the data of Table 1 .

Figure 3 presents clearly the increasing trend of the number of foreign visitors in Kosovo in the period of years 2017-2019. We can say that this increasing trend has been influenced by the increase in the number of foreign visitors who visited Kosovo for the above purposes, except for the purposes of business visits, work and transit travel, which have decreased each year. 
The Importance of Sustainable Development of Travel and Tourism Industry in the Turnover of Foreign Visitors: The Case of Kosovo 402

Table 2. Number of foreign visitors by country of origin in $2017-2019$

\begin{tabular}{|l|l|l|l|}
\hline Country & $\mathbf{2 0 1 7}$ & $\mathbf{2 0 1 8}$ & $\mathbf{2 0 1 9}$ \\
\hline Austria & 49,728 & 51,535 & 57,414 \\
\hline Belgium and & 29,703 & 31,625 & 33,692 \\
\hline $\begin{array}{l}\text { Bosnia } \\
\text { Herzegovina }\end{array}$ & 2,199 & 2,052 & 1,907 \\
\hline Great Britain & 47,564 & 53,090 & 58,235 \\
\hline France & 28,321 & 29,681 & 32,165 \\
\hline Germany & 188,637 & 208,550 & 229,486 \\
\hline Greece & 4,914 & 5,444 & 6,062 \\
\hline Netherlands & 14,988 & 16,032 & 17,128 \\
\hline Italy & 24,581 & 26,682 & 29,203 \\
\hline Croatia & 26,718 & 30,679 & 32,504 \\
\hline Montenegro & 143,502 & 144,851 & 154,715 \\
\hline North Macedonia & 989,780 & $1,046,605$ & $1,086,626$ \\
\hline Poland & 10,249 & 12,355 & 12,853 \\
\hline Serbia & $1,273,884$ & $1,342,711$ & $1,399,829$ \\
\hline US & 43,400 & 46,481 & 48,006 \\
\hline Albania & $1,164,973$ & $1,190,651$ & $1,272,024$ \\
\hline Slovenia & 12,954 & 13,203 & 12,779 \\
\hline Spain & 3,715 & 4,279 & 4,866 \\
\hline Turkey & 81,289 & 78,344 & 75,345 \\
\hline Switzerland & 171,928 & 187,374 & 207,906 \\
\hline Other & 167,555 & 185,561 & 189,590 \\
\hline Total & $\mathbf{4 , 4 8 0 , 5 8 2}$ & $\mathbf{4 , 7 0 7 , 7 8 5}$ & $\mathbf{4 , 9 6 2 , 3 3 5}$ \\
\hline
\end{tabular}

Source: Kosovo Agency of Statistics (KAS), Series 3: Economic Statistics, Hotel Statistics Q32020.

Table 2 shows the statistics of the number of foreign visitors by country of origin in 2017 - 2019. As it is shown in the Table the higher number of foreign visitors that visited Kosovo during the period of years 2017-2019 came from Serbia, Albania, North Macedonia, Germany, Switzerland, and Montenegro.

\section{Conclusions}

The travel and tourism industry is marking new developments day by day due to the fact that most people seek to take trips especially for leisure and recreation purposes, in a word to get away from the daily routine of work. But travel for other purposes is not lacking either. Regarding this, we say that other purposes of travel include visits to friends, family and relatives, business visits, work, transit tourism, and more.

It was seen that in Kosovo the highest number of visits by foreign visitors were trips for the purpose of visiting friends and relatives. It is worth mentioning that the number of foreign visitors has marked an increasing trend from 2017-2019. Also, the highest number of foreign visitors who visited Kosovo during the period 2017- 
2019 came from Serbia, Albania, North Macedonia, Germany, Switzerland, Montenegro.

Kosovo, although is a small country in terms of area and still underdeveloped in satisfactory levels, possesses destinations and tourist attractions which if used at the maximum level and rationally would contribute greatly to the economic development of the country contributing to increase the level of GDP.

Finally, we say that the travel and tourism industry, as an important part of the service sector, is one of the most developed industries today worldwide, and undoubtedly each country should pay special attention tosustainable development of this industry by creating appropriate conditions and policies for such a development.

\section{References:}

Adamopoulos, A., Thalassinos, I.E. 2020. Tourism Development and Economic Growth: A Comparative Study for the G-6 Leaders. European Research Studies Journal, 23(1), 368-380. DOI: $10.35808 / \mathrm{ersj} / 1555$.

Andrew, W.P., Damitio, J.W., Schmidgall, R.S. 2007. Financial Management for the Hospitality Industry. Pearson Prentice Hall, New Jersey, USA.

Godfrey, K. 1996. Towards sustainability? Tourism in the Republic of Cyprus. In Harrison, L.C. and Husbands, L. (Ed.), Practising Responsible Tourism: International Case Studies in Tourism Planning, Policy and Development. John Wiley \& Sons, Ney York, 58-79.

Hunter, C. 2002. Aspects of the Sustainable Tourism Debate from a Natural Resources Perspective. In Harris, R., Griffin, T., Williams, P. (Ed.), Sustainable Tourism: A Global Perspective. Butterwoth-Heinemann, Oxford, 3-23.

Kasimoğlu, M. 2012. Visions for Global Tourism Industry - Creating and Sustaining Competitive Strategies. InTech, Croatia.

Kosovo Agency of Statistics. 2020. Quarterly report of Hotel Statistics Q3 2020. Retrieved from: https://ask.rks-gov.net/media/5773/hotelerija-tm3-2020.pdf.

Lew, A., Hall, C.M., Timothy, D. 2008. World Geography of Travel and Tourism: A Regional Approach. Butterworth-Heinemann, Oxford, United Kingdom.

Lohmann, G., Netto, A.P. 2017. Tourism Theory: Concepts, Models and Systems. CABI, United Kingdom.

Manhas, P.S., Manrai, L.A., Manrai, A.K. 2016. Role of tourist destination development in building its brand image: A conceptual model. Journal of Economics, Finance and Administrative Science, 21(40), 25-29.

McCool, S.F., Moisey, R.N. 2008. Tourism, Recreation and Sustainability: Linking Culture and the Environment. CABI, United Kingdom.

Reçica, F., Millaku, B. 2011. Tourism Economy. The authors, Prishtina.

Segui-Amortegui, L., Clemente-Almendros, J.A., Median, R., Gala, M.G. 2019. Sustainability and Competitiveness in the Tourism Industry and Tourist Destinations: A Bibliometric Study. MDPI, Sustainability, 11(22), 6351.

Sharma, K.K. 2006. Tourism and Travel Industry. Sarup \& Sons, New Delhi, India.

Sharpley, R. 2009. Tourism Development and the Environment: Beyond Sustainability? Earthscan, UK and USA. 
The Importance of Sustainable Development of Travel and Tourism Industry in the Turnover of Foreign Visitors: The Case of Kosovo

404

Shaw, G., Williams, A.M. 2004. Tourism and Tourism Spaces. Sage Publications, London. Singal, M. 2015. How is the hospitality and tourism industry different? An empirical test of some structural characteristics. International Journal of Hospitality Management, 47, 116-119.

Tahiri, A., Kovaçi, I. 2017. Management in Tourism: Theoritical Approach. Research Centre, Peja.

Weaver, D. 2006. Sustainable Tourism: Theory and Practice. Elsevier Butterworth Heinemann, Oxford. 